\title{
STRATEGI LANGSUNG KESANTUNAN TINDAK DIREKTIF GURU TAMAN KANAK-KANAK
}

\author{
Anisa Ulfah \\ Fakultas Keguruan dan Ilmu Pendidikan, Universitas Islam Darul 'Ulum Lamongan \\ anisaulfah@unisda.ac.id
}

\begin{abstract}
The kindergarten students tend to learn by imitating people behavior and language hence the teacher itself must use polite and understandable language as stated in the standard academic qualifications and competence for kindergarten teacher. Politeness in language is closely related to the social norm in particular society. Thus the goal of this research is to describe a teachers' direct politeness in kindergarten that focus on politeness strategy function of politeness. This study used qualitatif method in the form of language research by using socio pragmatics. In collecting the data, the researcher was an observer. The data of this research was in the form of data form, strategy and the teacher's function in direct politeness accompanied by recording session in the learning activities in the class. According to data analysis, it was found a description politeness in kindergarden teacher that was explained in politeness strategy covered (1) direct strategy without politeness and (2) direct strategy with politeness covered. Based on the findings, the reseacher makes a conclusions is the use of direct strategy often regarded as less polite is often used by the teacher due to increase learning interaction.
\end{abstract}

Keywords: directive, language's politeness, teacher's language

\begin{abstract}
Abstrak : Berdasarkan standar kualifikasi akademik dan kompetensi, guru TK dituntut untuk mampu berinteraksi dengan bahasa yang efektif, empatik, dan santun. Oleh sebab itu, dalam memberikan arahan, petunjuk, perintah, bahkan larangan kepada siswa, guru harus mampu menyampaikannya dengan bahasa yang baik dan santun. Penelitian ini bertujuan untuk mendeskripsikan strategi guru dalam menyampaikan tindak direktif. Penelitian menggunakan pendekatan kualitatif dengan jenis penelitian bahasa yang dilakukan dengan kajian sosiopragmatik. Dalam proses pengumpulan data, peneliti merupakan pengamat nonpartisipan. Data penelitian ini berupa tuturan tindak direktif guru yang mengandung strategi dan respons siswa disertai konteks tuturan yang bersumber dari tuturan interaksi guru dan siswa dalam pembelajaran. Berdasarkan hasil analisis data diperoleh (1) strategi langsung tanpa penanda kesantunan dan (2) strategi langsung dengan penanda kesantunan. Kesimpulan penelitian ini ialah strategi langsung tanpa penanda kesantunan yang dinilai kurang santun memiliki frekuensi paling sering digunakan daripada strategi lain karena dipilih guru untuk meningkatkan keefektifan interaksi pembelajaran.
\end{abstract}

Kata Kunci: bahasa guru, kesantunan bahasa, tindak direktif,

\section{PENDAHULUAN}

Pendidikan Taman Kanak-Kanak merupakan pendidikan yang bertujuan mengembangkan potensi kecerdasan dan karakter anak pada usia emasnya. Oleh karena itu, pendidikan anak usia dini diselenggarakan sesuai dengan prinsipprinsip pendidikan yang telah ditentukan.
Di antaranya, melalui model pembelajaran yang dikemas dalam model bermain sambil belajar atau belajar seraya bermain. Bermain merupakan cara belajar anak yang mampu mengeksplorasi kemampuan anak mengenal lingkungan sekitar, menemukan, dan memanfaatkan objek-objek yang dekat dengan anak (Depdiknas, 2007a:10). 
Melalui aktivitas bermain, disadari atau tidak, anak telah belajar sesuatu yang berguna bagi hidupnya (Yus, 2011:33). Dengan cara demikian, pendidikan yang ditempuh tidak membebani anak, tetapi justru dapat memberikan pengalaman belajar bagi anak.

Anak usia tersebut merupakan anak yang masih dalam proses pertumbuhan dan perkembangan. Anak belajar dengan cara meniru orang-orang yang berada di lingkungannya. Hurlock (1980:107-108) menyebutkan bahwa masa usia dini yang disebutnya sebagai periode awal masa anak-anak merupakan usia kelompok, usia menjelajah, usia bertanya, usia meniru, dan usia kreatif. Lebih lanjut, dijelaskan bahwa yang paling menonjol dalam periode tersebut adalah anak meniru pembicaraan dan tindakan orang lain. Dengan demikian, peran guru dalam mencapai tujuan pendidikan TK tidak dapat dipandang sebelah mata meskipun pada prinsipnya pusat pembelajaran berada pada anak.

Kehadiran guru di kelas tidak hanya sebagai seorang pengajar melainkan juga sebagai pendidik dan pembimbing. Oleh sebab itu, guru harus pandai menciptakan suasana yang kondusif. Kondisi tersebut dapat diciptakan dengan memilih kata dan kalimat yang tepat saat berkomunikasi dengan siswa. Meskipun guru lebih mendominasi tetapi bagi siswa guru tetaplah contoh nyata dalam proses belajar berbahasa. Oleh karena itu, bahasa guru merupakan salah satu faktor yang dapat membantu menciptakan suasana belajar yang kondusif.

Dalam interaksi di kelas, guru banyak menggunakan tindak direktif untuk mencapai tujuan pembelajaran. Dalam menyampaikan tindak direktif tersebut guru diharuskan memiliki kompetensi yang sesuai dengan standar kualifikasi akademik dan kompetensi guru TK. Salah satu kompetensi inti yang harus dimiliki guru TK ialah "berkomunikasi secara efektif, empatik, dan santun dengan peserta didik" (Depdiknas, 2007b:5). Dengan kata lain, kualifikasi seorang guru TK juga dapat ditentukan melalui cara guru berkomunikasi. Guru TK dituntut dapat menyampaikan informasi, bertanya, memerintah, bahkan melarang siswa dengan bahasa yang santun, efektif, serta dengan cara yang empatik.

Bahasa guru tersebut berwujud kalimat yang dituturkan serta nada dan gerak tubuh yang menyertai tuturan. Chaer dan Agustina (2010:21-22) menyebutnya dengan aspek linguistik dan aspek paralinguistik. Kedua aspek tersebut membangun komunikasi bahasa. Aspek paralinguistik berkaitan dengan jarak dan gerak-gerik tubuh. Secara lebih spesifik, Taylor (1990:43) menyebutnya dengan gestur, yang merupakan gerakan tangan untuk memberikan tekanan saat percakapan terjadi secara langsung. Dengan demikian, seorang guru TK harus memahami strategi berkomunikasi yang efektif, empatik, dan santun selama proses interaksi pembelajaran. Interaksi pembelajaran tersebut harus terbangun secara siklikal mulai dari (1) menyiapkan kondisi psikologis siswa, (2) memberikan pertanyaan atau tugas sebagai undangan kepada siswa untuk merespons, (3) respons siswa, dan (4) reaksi guru terhadap respons siswa (Depdiknas, 2007b:5).

Penggunaan tindak direktif dalam proses interaksi pembelajaran antara guru dan siswa tentu berpengaruh dalam kegiatan pembelajaran dan proses peneladanan bagi siswa. Guru sebagai anggota masyarakat akan dianggap telah mampu memberikan teladan bagi anak bila tuturan dan tindakan guru telah sesuai dengan nilai sosial yang berlaku dalam masyarakat. Oleh karena itu, bahasa yang dituturkan guru harus santun karena bahasa merupakan cerminan pribadi penuturnya. Dengan kata lain, secara tidak langsung bahasa yang dituturkan guru merupakan ejawantah yang dapat menunjukkan nilainilai sosial budaya masyarakat penuturnya. Suyitno (2004:88) menjelaskan bahwa berbahasa tidak dapat mengabaikan norma dan nilai sosial yang menyangkut nilai etis, yaitu kesopanan, kelaziman, dan 
kewajaran. Dengan demikian, kesopanan, kelaziman, dan kewajaran seorang guru dalam proses peneladanan pengembangan kemampuan berbahasa anak didasarkan pada nilai sosial yang berlaku dalam lingkungan sosial mereka.

Berdasarkan paparan tersebut dapat diketahui bahwa kegiatan interaksi pembelajaran di TK tidak dapat dilepaskan dari kegiatan guru menyampaikan informasi, memberikan pertanyaan, dan memerintah. Setiap tuturan dan tindakan guru TK dapat menjadi panutan bagi para siswanya. Oleh karena itu, tuturan guru menjadi salah satu topik yang menarik untuk diteliti. Pertimbangan-pertimbangan yang dipilih guru saat bertutur untuk memberikan tindak direktif kepada siswa tentu dapat menggambarkan kesantunan bahasa guru, khususnya dalam tindak direktif. Oleh sebab itu, peneliti bermaksud mendeskripsikan bagaimana strategi kesantunan tindak direktif guru TK.

\section{KAJIAN PUSTAKA}

Penelitian tentang kesantunan bahasa serta tindak direktif pernah dilakukan oleh beberapa peneliti sebelumnya. Pertama, penelitian yang dilakukan oleh Suharto (2004) dengan judul Kesantunan Berbahasa Indonesia dalam Interaksi Belajar-Mengajar di Kelas 2 SLTP. Penelitian tersebut mengungkapkan bahwa interaksi yang dilakukan guru dengan siswa, siswa dengan siswa, dan siswa dengan guru menunjukkan adanya wujud, strategi, dan fungsi kesantunan yang beragam. Kedua, penelitian yang dilakukan oleh Ramadhan (2007) dengan judul Representasi Kesantunan Tindak Tutur Berbahasa Indonesia Guru dalam Interaksi Pembelajaran di Kelas. Penelitian tersebut memaparkan tentang bentuk, fungsi, strategi, dan penggunaan penanda kesantunan tindak tutur. Tindak tutur yang diteliti difokuskan pada tindak direktif dan ekspresif. Penelitian tersebut juga dilakukan pada jenjang sekolah menengah atas.
Ketiga, penelitian serupa juga dilakukan oleh Amiruddin (2011) dengan judul Penggunaan Kesantunan Tindak Direktif Berbahasa Indonesia Guru dalam Pembelajaran di Kelas. Fokus penelitian tersebut ialah wujud, strategi, dan fungsi tindak direktif. Penelitian tersebut merupakan penelitian yang dekat dengan penelitian yang dilakukan karena konteks penelitiannya difokuskan pada tindak direktif guru. Fokus penelitian tersebut dijadikan sebagai inspirasi, kemudian agar tidak terjadi replikasi penelitian tersebut, dirumuskan fokus penelitian yang berbeda. Fokus penelitian yang dikembangkan ialah penelitian tidak hanya menjabarkan hasil temuan tentang kesantunan fungsi tindak direktif tetapi juga memaparkan hasil penelitian tentang fungsi kesantunan tindak direktif guru. Adapun fokus lain yang ditambahkan ialah deskripsi respon siswa dalam menanggapi tindak direktif guru TK yang pada penelitian terdahulu belum dilakukan.

Tindak direktif merupakan salah satu jenis tindak ilokusi yang terdapat dalam teori tindak tutur. Tuturan menjadi wujud adanya pemakaian bahasa. Penutur dan mitra tutur sebagai orang yang memakai bahasa dapat berperan secara bergantian dalam suatu tindak berbahasa. Suatu tuturan dapat dipahami secara berbeda oleh mitra tutur yang memiliki pengetahuan berbeda. Secara umum ada dua jenis ujaran, yaitu ujaran konstantif dan performatif (Austin, 1962 \& Cummings, 1999). Ujaran konstantif mengacu pada keadaan benar atau salah. Adapun ujaran performatif dapat memunculkan adanya suatu tindakan. Kedua ujaran tersebut dapat berwujud kalimat berita, kalimat, tanya, maupun kalimat perintah.

Berkaitan dengan wujud ujaran atau tuturan tersebut, apabila ditranskripsi menjadi bahasa tulis, maka wujud tuturan tersebut dapat berwujud beberapa jenis kalimat. Leech (1983:179) menyebutkan bahwa berdasarkan kajian sintaksis, kalimat dibedakan menjadi kalimat: deklaratif, interogatif, dan imperatif; beradasarkan 
kajian semantik, kalimat tersebut berisi proposisi, pertanyaan, dan perintah; sedangkan berdasarkan kajian pragmatik, kalimat tersebut berisi pernyataan, pertanyaan, dan impositif. Kalimat deklaratif ialah kalimat yang berisi informasi tentang suatu kebenaran. Kalimat interogatif ialah kalimat yang berisi pertanyaan yang mengharuskan pendengar memberikan jawaban. Adapun kalimat impertaif ialah kalimat yang isinya meminta pendengar untuk melakukan sesuatu sebagaimana kalimat yang dituturkan.

Adanya sebuah komunikasi yang berwujud kalimat-kalimat tersebut mampu menghasilkan tindakan sebagai hasil adanya tuturan yang disebut dengan perilaku tindak tutur. Tindak tutur merupakan teori yang berhubungan langsung dengan kajian pragmatik. Teori tindak tutur diperkenalkan pertama kali oleh Austin (1962:12) yang menjelaskan bahwa ketika seorang menuturkan kalimat, ia tidak hanya menyatakan sesuatu, tetapi juga mengandung tindakan sebagai wujud tuturan. Lebih lanjut dijelaskan bahwa tindak tutur dibagi menjadi tiga bagian utama, yaitu tindak lokusi, ilokusi, dan perlokusi. Adapun tindak tutur lokusi yang dikembangkan Searle (1981:12-14) meliputi tindak (1) asertif-representatif, yakni tindak tutur menjelaskan apa dan bagaimana sesuatu sebagaimana adanya; (2) komisif, yakni tindak tutur yang mengikat penutur untuk melakukan sesuatu di masa yang akan datang; (3) direktif, yakni tindak tutur yang berfungsi mendorong pendengar melakukan sesuatu; (4) ekspresif, yaitu tindak tutur yang menyangkut perasaan dan sikap; dan (5) deklaratif, yakni tindak tutur yang menghubungkan isi proposisi dengan realitas yang sebenarnya.

Berkaitan dengan teori tindak tutur tersebut, ada dua jenis tindak tutur, yaitu tindak tutur langsung dan tidak langsung (Yule, 1996:95-96). Berdasarkan strukturnya, terdapat tiga macam kalimat dalam tindak tutur, yaitu deklaratif, interogatif, dan imperatif yang masingmasing berfungsi untuk menyatakan, menanyakan, dan memerintah. Apabila ada hubungan langsung antara struktur dengan fungsi, maka disebut tindak tutur langsung. Apabila tidak ada hubungan langsung antara struktur dan fungsinya maka disebut tindak tutur tidak langsung. Dalam interaksi pembelajaran, guru tentu menggunakan ketiga jenis tuturan tersebut. Dikatakan demikian karena saat mengajarkan tentang suatu materi pembelajaran, guru tentu memberikan penjelasan materi, memberikan pertanyaan kepada siswa, serta memberikan tugas, baik secara langsung maupun tidak langsung.

\section{METODE PENELITIAN}

Penelitian tentang kesantunan tindak direktif bahasa Indonesia guru TK ini menggunakan pendekatan kualitatif. Adapun jenis penelitian yang digunakan dalam penelitian ini ialah penelitian bahasa karena dilakukan pada satu subjek penelitian dengan satu latar belakang tertentu, yakni peristiwa tutur dalam konteks interaksi pembelajaran di TK. Adapun berdasarkan jenis keilmuannya, penelitian dilakukan dengan kajian sosiopragmatik. Penggunaan jenis ini dilandasi oleh pertimbangan bahwa penelitian tersebut memiliki karakteristik yang sesuai dengan fokus penelitian. Jenis tersebut dapat digunakan untuk mengungkapkan berbagai permasalahan yang diungkapkan secara implisit sehingga dapat diketahui kesantunan tindak direktif yang sebenarnya melekat pada bahasa guru TK sesuai dengan latar belakang penutur bahasa yang diteliti, yakni budaya Jawa.

Sumber data penelitian kesantunan tindak direktif guru TK ialah tuturan tindak direktif bahasa Indonesia guru TK saat berinteraksi dengan siswa di kelas dan konteksnya. Adapun data dalam penelitian ini ialah data strategi kesantunan tindak direktif guru TK. Pengumpulan data dalam penelitian ini dilakukan dengan dua teknik, yaitu perekaman dan pengamatan. Perekaman dilakukan untuk menghimpun 
tuturan guru saat berinteraksi dengan siswa di kelas dengan menggunakan alat rekam audiovisual. Perekaman dilakukan peneliti dengan sepengetahuan subjek penelitian.

Analisis data dilakukan selama proses pengumpulan data dan setelah data terkumpul. Analisis data dilakukan secara interaktif sehingga data dianalisis selama dalam proses pengumpulan data. Secara garis besar, analisis data dilakukan dengan empat kegiatan yang dilakukan secara bersamaan, yaitu (1) pengumpulan data, (2) reduksi data, (3) penyajian data, dan (4) penyimpulan serta verifikasi. Kegiatan reduksi data dilakukan selama pengumpulan dan setelah data terkumpul. Sumber data ditranskrip untuk mendapatkan data tuturan tindak direktif guru. Kemudian data dianalisis dengan tahap identifikasi data, kodifikasi data, dan klasifikasi data.

\section{HASIL DAN PEMBAHASAN}

Strategi kesantunan tindak direktif guru TK dijelaskan melalui subbab yang meliputi (a) strategi langsung tanpa penanda kesantunan, (b) strategi langsung dengan penanda kesantunan, dan (c) strategi tidak langsung. Berikut ini merupakan paparan lengkap tentang strategi kesantunan tindak direktif guru TK.

\section{Strategi Langsung tanpa Penanda Kesantunan Tindak Direktif Guru}

Tindak direktif guru yang disampaikan dengan strategi langsung menggunakan kalimat imperatif berjumlah 59 kalimat. Fungsi tindak direkif yang disampaikan dengan strategi langsung, yaitu (1) perintah, (2) permintaan, (3) pemberian petunjuk, (4) larangan, (5) nasihat, dan (6) peringatan.

\section{Tindak Memerintah}

Berdasarkan hasil analisis data ditemukan bahwa dalam memberikan tindak direktif berupa perintah, guru menggunakan strategi langsung. Kutipan [1] berikut ini merupakan salah satu data yang menunjukkan penggunaan strategi kesantunan langsung yang digunakan guru dalam memerintah.

[1] Konteks: Dituturkan saat seorang siswa menyela siswa lain yang sedang bercerita yang ditunjuk guru untuk bercerita.

Siswa 1 : (bercerita) (1)

Siswa 2 : (menyela-nyela temannya yang bercerita) (2)

Guru: "Dengarkan dulu temannya cerita!" (3)

Siswa 2 : (menoleh ke guru kemudian menatap ke temannya yang bercerita) (4)

[RC/Im/TL/006]

Kutipan [1] menunjukkan adanya strategi langsung yang digunakan guru dalam memberikan tindak perintah kepada siswa. Tindak tersebut dinyatakan secara langsung melalui tuturan (3), yakni "Dengarkan dulu temannya cerita!". Tuturan tersebut dinyatakan guru saat ada siswa yang selalu menyela dan tidak mendengarkan temannya bercerita. Guru menggunakan kalimat imperatif dengan penanda intonasi turun pada akhir kalimat sehingga bila dituliskan, maka tuturan tersebut diakhiri dengan tanda seru. Pilihan kata yang menunjukkan strategi langsung juga tampak pada kata verba dengarkan yang menunjukkan aktivitas yang harus dilakukan siswa.

Dengan demikian, tindakan yang dilakukan siswa tampak secara eksplisit dalam tuturan. Oleh sebab itu, strategi yang digunakan guru dalam memberikan tindak perintah dinyatakan secara langsung. Ibrahim (1993:28) menggolongkan tindak memerintah ke dalam tindak requirements. Adapun strategi langsung yang dimaksud ialah bahwa guru menuturkan secara langsung tindakan yang dilakukan siswa dalam tuturannya, yakni memerintah siswa untuk melakukan sesuatu dengan kata verba dengarkan dan pindah menggunakan kalimat imperatif.

Temuan penelitian tersebut juga sejalan dengan hasil penelitian Amiruddin (2011) yang mengungkapkan bahwa perintah guru di SMA juga diberikan dengan kalimat imperatif. Hal tersebut dapat dipahami bahwa dalam interaksi pembelajaran, termasuk di TK, guru 
memberikan perintah kepada siswa. Digunakannya kalimat imperatif dalam memberikan perintah tentu sesuai dengan situasi atau konteks yang terjadi di kelas. Dengan demikian, perintah yang diberikan guru menggunakan kalimat imperatif dinyatakan sebagai penggunaan strategi langsung.

\section{Tindak Meminta}

Kutipan [2] berikut ini merupakan salah satu bukti penggunaan strategi langsung yang digunakan guru dalam tindak meminta.

[2] Konteks: Dituturkan saat siswa memanggil guru untuk meminta izin mengacak angkaangka yang telah berhasil diurutkan, tetapi guru belum memeriksanya.

$\begin{array}{ll}\text { Siswa } & \begin{array}{l}\text { : Miss, sudah." (bersiap mengacak } \\ \text { angka) (1) }\end{array} \\ \text { Guru } & \text { "Bentar, tunggu dulu!" (2) } \\ & \text { (menoleh kepada siswa sambil } \\ & \text { melihat angka-angka yang telah } \\ \text { diurutkan siswa) } & \\ \text { Siswa } & \text { (menoleh ke guru kemudian } \\ & \text { membiarkan tugasnya) (3) }\end{array}$

[RC/Im/TL/030]

Kutipan [2] menunjukkan bahwa guru menggunakan strategi langsung dalam memberikan tindak meminta kepada siswa. Tindak tersebut dinyatakan guru secara langsung melalui tuturan (2), yaitu "Bentar, tunggu dulu!'. Tuturan tersebut dinyatakan guru saat meminta siswa untuk menunggu karena guru masih memeriksa hasil pekerjaan siswa lain sehingga belum bisa memeriksa hasil pekerjaan siswa yang memanggilnya. Tuturan (2) yang dinyatakan guru tersebut menggunakan strategi langsung karena dinyatakan dengan intonasi turun. Oleh sebab itu, apabila dituliskan tuturan (2) menggunakan tanda seru di akhir kalimat. Selain itu, guru juga menggunakan kata verba dasar tunggu sebagai wujud tindakan yang harus dilakukan siswa. Rahardi (2005:80) menjelaskan bahwa kalimat imperatif permintaan ialah kalimat dengan kadar suruhan sangat halus. Dengan kata lain, tindak permintaan yang disampaikan guru dengan kalimat imperatif termasuk menggunakan strategi langsung. Dalam penelitian juga ditemukan Ramadhan (2007) dan Amiruddin (2011), sedangkan pada penelitian Suharto (2004), tindak meminta tidak ditemukan sebagaimana pada laporan hasil penelitian yang dituliskannya. Dengan demikian, selain memerintah, ada kalanya guru juga memberikan tindak permintaan kepada siswa. Hal tersebut menunjukkan bahwa guru tidak menunjukkan keotoritasannya di kelas. Dikatakan demikian karena lazimnya tindak permintaan disertai dengan sikap penutur yang lebih merendah (Rahardi, 2005:80).

\section{Tindak Memberikan Petunjuk}

Kutipan [3] berikut ini merupakan salah satu bukti yang menunjukkan adanya penggunaan strategi langsung dalam tindak memberikan petunjuk kepada siswa.

[3] Konteks: Dituturkan saat guru menjelaskan cara mengerjakan tugas kepada siswa.

Guru : "Dihitung dulu, ditulis di sini! (1) Kemudian silakan ditarik garis! (2) Cari! (3) Misalnya, 'Oh, Miss, ini ada sepuluh'. (4) Cari di sini yang tulisannya se..pu..luh! (5) Berarti huruf depannya apa ya? (6) Se..?" (7) (menunjuk bagian gambar yang akan dikerjakan siswa)

Siswa 1 : "Sepuluh, Miss." (8)

Siswa 2 : "S, Miss." (9) (menoleh ke guru

kemudian membiarkan tugasnya)

Guru : "Iya. (10) Bisa?" (11)

Siswa : "Bisa." (12)

[RC/Im/TL/010]

Kutipan [3] menunjukkan adanya penggunaan strategi langsung dalam tindak guru memberikan petunjuk kepada siswa dalam proses pembelajaran. Tindak tersebut dinyatakan guru melalui tuturan (1), (2), (3), dan (4). Misalnya pada tuturan (1), guru menyatakan pemberian petunjuk dengan kalimat "Dihitung dulu, ditulis di sini!". Tuturan tersebut dinyatakan guru sambil menunjukkan bagian gambar yang harus dihitung siswa. Guru memberikan petunjuk dengan detail cara mengerjakan tugas siswa. Guru menggunakan beberapa 
kalimat imperatif dalam memberikan petunjuk tersebut. Tindak memberikan petunjuk disebut Ibrahim (1993:28) dengan tindak menginstruksikan. Pilihan kata yang menunjukkan kelangsungan strategi yang digunakan guru juga tampak pada pilihan kata verba yang digunakan guru, yakni dihitung, ditulis, ditarik, dan cari. Dengan kata lain, tindakan yang harus dilakukan siswa tampak pada tuturan guru secara eksplisit. Temuan tersebut sejalan dengan temuan Amiruddin (2011) bahwa di tingkat SMA, guru juga memberikan petunjuk kepada siswa dengan strategi tidak langsung dalam memberikan petunjuk. Adapun pada penelitian ini, guru menggunakan strategi langsung. Hal tersebut menunjukkan bahwa guru mempertimbangkan siswa sebagai mitra tutur. Dalam hal ini mitra tutur guru ialah siswa TK sehingga guru menggunakan strategi langsung sehingga petunjuk guru dapat tersampaikan secara efektif.

\section{Tindak Melarang}

Kutipan [4] berikut ini merupakan salah satu data yang menunjukkan adanya penggunaan strategi langsung dalam tindak melarang yang dituturkan guru.

[4] Konteks: Dituturkan saat siswa mengerjakan tugas, Arya menggangu Abel.

Guru : "Arya, nggak boleh gitu!” (1)

Siswa : (menatap guru tetapi masih senyumsenyum kepada Abel) (2)

[RC/Im/TL/015]

Kutipan [4] menunjukkan bahwa
dalam proses pembelajaran guru
menggunakan strategi langsung dalam
memberikan tindak larangan kepada siswa.
Tindak larangan tersebut dinyatakan
melalui tuturan (1), yakni "Arya, nggak
boleh gitu!" dan "Yang belum dilihat
jangan dulu!". Tuturan (1) pada kutipan [4]
dinyatakan guru kepada salah satu siswa
bernama Arya yang mengganggu temannya
saat proses pembelajaran. Tindak larangan
tersebut juga ditujukan guru untuk semua
siswa agar tidak mengacak angka sebelum
diizinkan guru. Tindak tersebut dinyatakan

guru secara langsung menggunakan kalimat imperatif. Larangan juga dapat ditunjukkan oleh penggunaan kata nggak boleh dan jangan sebagai penanda tindak larangan. Dengan demikian, guru menggunakan strategi langsung dalam memberikan tindak larangan kepada siswa.

Tindak larangan merupakan jenis tindak prohibities (Ibrahim, 1993:28). Adapun penggunaan kalimat imperatif tersebut menunjukkan adanya strategi langsung yang digunakan guru saat memberikan larangan kepada siswa. Larangan tersebut dinyatakan secara langsung dalam kata nggak boleh dan jangan sebagai penanda tindak larangan. Hal tersebut sejalan dengan paparan Rahardi (2005:109) yang menjelaskan bahwa tindak melarang umumnya menggunakan kata jangan. Adapun Soedjito (1988:53) menjelaskan bahwa penggunaan kata ingkar jangan dapat dilekatkan pada kata harap, hendaknya, atau hendaklah yang dapat memperhalus larangan. Namun, dalam penelitian ini hal tersebut tidak ditemukan. Dengan demikian, tindak larangan guru yang dinyatakan dengan kalimat imperatif termasuk penggunaan strategi langsung dalam tindak melarang.

\section{Tindak Menasihati}

Kutipan [5] berikut ini merupakan salah satu data yang menunjukkan adanya penggunaan strategi langsung dalam tindak menasihati yang dituturkan guru.

[5] Konteks: Dituturkan saat salah satu siswa mengadu kehilangan pensil.

Guru: "Teman-teman, kalau dikasih pensil sama Miss Arie disimpan baik-baik ya!" (1)

Siswa : "Iya, Miss." (2) (Menganggukanggukan kepala)

[RC/Im/TL/034]

Kutipan [5] merupakan tuturan guru yang menunjukkan adanya tindak menasihati yang dituturkan guru dengan kalimat imperatif. Hal tersebut menunjukkan adanya strategi langsung yang digunakan guru. Tindak menasihati 
tersebut dituturkan guru melalui tuturan (1), yakni "Teman-teman, kalau dikasih pensil sama Miss Arie disimpan baik-baik ya!". Tuturan (1) tersebut dinyatakan guru saat salah seorang siswa mengadu kehilangan pensil. Kemudian setelah guru memberikan pensil kepada siswa tersebut, guru menasihati semua siswa agar menyimpan pensil dengan baik agar tidak hilang lagi. Kelangsungan tindak direktif tersebut juga tampak dengan penggunaan kata verba dikasih dan disimpan serta kata seru ya yang ada pada tuturan (1).

Tindak menasihati merupakan salah satu tindak advisories (Ibrahim, 1993:29). Tindak direktif tersebut dinyatakan dengan strategi langsung karena penggunaan kata verba dikasih dan disimpan serta kata seru ya yang ada menunjukkan kelangsungan fungsi kalimat. Tindak menasihati juga ditemukan pada penelitian Amiruddin (2011), tetapi pada penelitian Suharto (2004) dan Ramadhan (2007) tindak menasihati tidak ditemukan. Hal tersebut menunjukkan bahwa tindak menasihati yang ditemukan pada penelitian ini mendukung hasil penelitian sebelumnya. Sedikit berbeda dengan penelitian ini, Rahardi (2005:114) mengungkapkan bahwa dalam penelitian yang dilakukannya ditemukan adanya tindak menganjurkan yang ditandai dengan kata hendaknya dan sebaiknya. Namun, berdasarkan konteks situasinya, tindak menasihati lebih dipilih dengan mempertimbangkan peran guru sebagai pendidik di kelas sehingga sudah sepatutnya guru memberikan nasihat kepada siswanya.

\section{Tindak Memperingatkan}

Kutipan [6] berikut ini merupakan salah satu data yang menunjukkan adanya penggunaan strategi langsung dalam tindak memperingatkan yang dituturkan guru.

[6] Konteks: Dituturkan saat beberapa siswa masih ada yang di kelas komputer, sebagian masih ada yang mengerjakan, dan sebagian lagi ada yang sudah bermain sambil berteriakteriak.

Guru : "Tanpa teriakan ya!” (1)
Siswa : (menoleh ke guru kemudian diam) (2)

[RC/Im/TL/024]

Kutipan [6] menunjukkan bahwa
dalam proses pembelajaran guru
menggunakan strategi langsung dalam
memberikan tindak memperingatkan siswa.

Tindak memperingatkan tersebut dituturkan guru melalui tuturan (1), yakni "Tanpa teriakan ya!" dan "Jangan lupa menuliskan nama ya!’. Kedua tuturan tersebut merupakan tindak memperingatkan berdasarkan konteks tuturan yang ada. Pada tuturan (1) kutipan [6], guru memperingatkan siswa yang bermain agar tidak berteriak karena dapat mengganggu temannya yang belum selesai mengerjakan tugas. Tindak direktif tersebut dipahami siswa sehingga direspons siswa dengan tidak lagi berteriak.

Hal tersebut menunjukkan bahwa kata jangan tidak hanya digunakan untuk mengungkapkan tindak larangan. Ibrahim (1993:28) menggolongkan tindak memperingatkan ke dalam tindak advisories. Ramlan (1986:46) menjelaskan bahwa salah satu tanda kalimat larangan ialah digunakannya kata jangan pada awal kalimat. Temuan penelitian ini juga berbeda dengan penelitian Amiruddin (2011) yang mengungkapkan bahwa guru menggunakan kata jangan saat melarang siswa. Namun, pada penelitian ini kata jangan digunakan guru untuk memberikan peringatan kepada siswa. Hal tersebut belum ditemukan pada penelitian Suharto (2004) dan Ramadhan (2007). Peringatan yang dinyatakan guru dengan kata tanpa teriakan dan jangan lupa menunjukkan kejelasan maksud guru dalam kalimat imperatif.

\section{Strategi Langsung dengan Penanda Kesantunan Tindak Direktif Guru}

Berdasarkan hasil analisis data didapatkan temuan bahwa guru juga menggunakan strategi langsung dengan penanda kesantunan, meliputi (a) ayo, (b) silakan, (c) coba, dan (d) ya. Tindak direktif guru yang disampaikan dengan 
strategi langsung menggunakan kalimat imperatif berpenanda kesantunan berjumlah 43 kalimat. Berikut ini merupakan paparan dan pembahasannya.

\section{Penanda Kesantunan Ayo}

Kutipan [7] berikut ini merupakan salah satu data yang menunjukkan adanya penggunaan strategi langsung dengan penanda kesantunan dalam tindak memperingatkan yang dituturkan guru.

[7] Konteks: Dituturkan saat ada beberapa siswa tidak ikut membaca doa sebelum makan.

Guru : "Ayo, diulangi lagi!" (1)

Siswa : (membaca doa dengan suara lebih lantang) (2)

[RC/Im/TL/028]

Kutipan [7] menunjukkan bahwa tuturan guru yang berfungsi sebagai perintah juga dituturkan dengan strategi langsung berpenanda kelangsungan ayo. Tindak memerintah tersebut dinyatakan melalui tuturan (1), yakni "Ayo, diulangi lagi!’. Tuturan (1) tersebut dinyatakan guru saat siswa membaca doa sebelum makan, tetapi karena hanya beberapa siswa saja yang ikut berdoa maka guru memerintah siswa untuk mengulanginya lagi. Strategi yang digunakan guru untuk memberikan tindak direktif perintah tersebut ialah strategi langsung dengan kata ayo sebagai penanda kesantunan. Penggunaan kata ayo menjadikan tuturan menjadi kalimat imperatif sehingga diakhiri dengan intonasi turun. Selain itu, guru juga menggunakan kata diulangi sebagai bentuk tindakan yang harus dilakukan siswa. Dengan demikian, kutipan [7] merupakan tuturan tindak direktif guru yang berfungsi sebagai perintah. Meskipun pada umumnya, penggunaan kata ayo dapat menjadikan fungsi tuturan sebagai ajakan, tetapi dalam konteks yang ada, kutipan [7] berikut ini merupakan salah satu tuturan guru yang menggunakan kata ayo, tetapi tidak lagi berfungsi sebagai ajakan.

Paparan data tersebut menunjukkan adanya temuan penelitian bahwa penggunaan strategi langsung dengan penanda kesantunan ayo tidak hanya mengandung tindak direktif ajakan. Hal tersebut merupakan penyanggah paparan Rahardi (2005:106) yang memaparkan bahwa umumnya kalimat imperatif yang bermakna ajakan ditandai dengan penggunaan kata mari dan ayo. Dengan kata lain, tindak direktif memerintah yang ada pada tuturan guru hanya dapat dipahami dengan menyertakan konteksnya. Di sisi lain, kelangsungan tindak direktif pada kutipan [7] juga tampak pada kata verba diulangi yang dituturkan guru. Bentuk verba tersebut berbeda dengan paparan Chair (2010:90) yang menyebutkan bahwa ciri umum kalimat imperatif ialah digunakannya verba dasar atau verba tanpa prefiks me-. Berdasarkan paparan tersebut dapat dipahami bahwa meskipun kata verba yang digunakan guru bukan kata verba dasar, tetapi dengan adanya penanda kesantunan ayo tetap menjadikan kalimat guru bermodus imperatif. Adapun hasil penelitian Amiruddin (2011) tidak memaparkan digunakannya penanda kesantunan ayo dalam tindak direktif guru. Dengan demikian, kalimat imperatif tidak hanya ditandai dengan penggunaan verba dasar, tetapi verba berprefiks $d i$ - juga dapat menjadikan kalimat bermodus imperatif ditambah dengan penggunakan penanda kesantunan ayo sebagai petunjuk penggunaan strategi langsung.

\section{Penanda Kesantunan 'Silakan'}

Kutipan [8] berikut ini merupakan salah satu data yang menunjukkan penggunaan kata silakan dalam tindak memerintah guru.

[8] Konteks: Dituturkan saat guru menjelaskan tugas yang akan dikerjakan siswa.

Guru : "Itu tadi halaman 6. (1) Sekarang halaman 9, teman-teman. Silakan menghitung lagi!" (3)

Siswa : (siswa mulai menghitung dengan bahasa Jawa bersama-sama) (4)

[RC/Im/TL/009]

Kutipan [8] menunjukkan bahwa tuturan guru yang berfungsi sebagai perintah juga dituturkan dengan strategi 
langsung menggunakan penanda kesantunan silakan. Tindak tersebut dituturkan guru melalui tuturan (3), yakni "Silakan menghitung lagi!'. Tuturan (3) dinyatakan guru saat menjelaskan tugas siswa tentang berhitung kemudian guru menyilakan siswa untuk berhitung sesuai dengan yang sudah dijelaskan guru pada tugas yang sebelumnya. Penggunaan kata silakan menjadikan tuturan guru berintonasi turun karena kata tersebut juga sebagai salah satu penanda kalimat imperatif. Dengan demikian, tindak memerintah juga dituturkan guru dengan strategi langsung yang santun dengan penggunaan kata silakan.

Tindak memerintah yang dituturkan guru menggunakan penanda kesantunan silakan dalam kalimat imperatif menunjukkan penggunaan strategi langsung yang digunakan guru. Ramlan (1986:45) menyebut kalimat tersebut dengan kalimat persilaan yang juga mengharapkan tanggapan berupa tindakan dari mitra tutur. Lebih lanjut dijelaskan bahwa kalimat persilaan menggunakan kata silakan atau dipersilakan di awal kalimat serta boleh tanpa memberikan $\mathrm{S}$ pada kalimat. Hal tersebut sejalan dengan temuan penelitian bahwa dalam tuturan guru kata silakan berada di awal kalimat dan tanpa S. Selain itu, penggunaan kata silakan menunjukkan bahwa guru tetap menggunakan kalimat yang santun meskipun yang diajak bicara ialah siswa TK. Hal tersebut juga menunjukkan kerendahan hati guru. Temuan penelitian tersebut menguatkan hasil penelitian Ramadhan (2007) yang juga memaparkan bahwa guru di tingkat SMA juga menggunakan kata silakan saat berinteraksi dengan siswa.

\section{Penanda Kesantunan 'Coba'}

Berdasarkan hasil analisis data dapat diketahui bahwa dalam meminta guru juga menggunakan kata coba sebagai penanda kesantunan dalam strategi langsung yang dituturkan guru. Kata coba yang melekat pada tindak meminta guru dapat memberikan keleluasaan kepada siswa dalam melakukan tindak yang dimaksudkan guru. Kutipan [9] berikut ini merupakan salah satu data yang menunjukkan penggunaan kata coba dalam tindak meminta guru.

[9] Konteks: Dituturkan saat suara mengaji pada speaker tidak terdengar karena siswa ramai.

Guru : "Coba dengar dulu!" (1)

Siswa : (saling pandang kemudian diam) (2)

[RC/Im/TL/089]

Kutipan [9] menunjukkan bahwa guru menggunakan kata coba dalam memberikan tindak meminta kepada siswa. Tindak tersebut dituturkan guru melalui tuturan (1), yakni "Coba dengar dulu!". Tuturan (1) dinyatakan guru saat suara mengaji tidak terdengar karena situasi kelas yang ramai. Akhirnya guru meminta siswa untuk mendengarkan suara mengaji yang ada di speaker agar dapat mengikuti bacaan yang sesuai dengan bacaan di speaker. Penggunaan kata coba menjadikan tuturan guru berintonasi turun sehingga dituliskan dengan kalimat imperatif. Dengan demikian, tindak meminta dituturkan guru dengan strategi langsung dengan penggunaan kata coba sebagai penanda kesantunan.

Penggunaan kata coba pada tindak meminta yang dituturkan guru tersebut menunjukkan adanya penggunaan strategi langsung dalam tindak direktif guru. Penggunaan kata coba tersebut berbeda dengan paparan Rahardi (2005:97) yang menjelaskan bahwa lazimnya tindak permintaan ditandai dengan kata tolong atau frasa lain yang berarti minta. Adapun pada kutipan [9] fungsi tindak direktif meminta yang dilakukan guru dapat dipahami melalui konteks yang menyertai tuturan. Dengan kata lain, penanda imperatif coba juga dapat memiliki fungsi tindak meminta sesuai dengan konteks kata tersebut dituturkan. Di sisi lain, kelangsungan tindak direktif guru juga tampak pada penggunaan kata verba dasar dengar. Hal tersebut sejalan dengan 
paparan Chaer (2010:90) yang menyatakan bahwa salah satu ciri kalimat imperatif ialah digunakannya kata verba dasar pada kalimat tersebut. Adapun pada penelitian sebelumnya yang dilakukan Ramadhan (2007) juga ditemukan penggunaan kata coba untuk menyatakan permintaan. Dengan demikian, temuan data yang menunjukkan penggunaan kata coba untuk menyatakan permintaan tersebut mendukung penelitian sebelumnya sekaligus merupakan bantahan bahwa tindak meminta tidak hanya ditandai dengan penanda kesantunan tolong atau mohon.

\section{Penanda Kesantunan 'Ya'}

Kutipan [10] berikut ini merupakan salah satu data yang menunjukkan penggunaan kata ya pada tindak memerintah guru.

[10] Konteks: Dituturkan setelah beberapa siswa sudah kembali dari kelas komputer, guru menunjuk siswa yang belum komputer agar ke kelas komputer.

Guru: "Yang belum komputer langsung ke kelas komputer ya!"

Siswa : "Iya, Miss." (berlarian keluar kelas menuju kelas komputer)

Guru: (geleng-geleng kepala)

[RC/Im/TL/022]

Kutipan [10] tersebut menunjukkan bahwa guru juga menggunakan kata seru ya dalam memerintah siswa. Tindak tersebut dituturkan guru melalui tuturan (1), yakni "Yang belum komputer langsung ke kelas komputer ya!". Tuturan (1) dinyatakan guru saat ada beberapa siswa kembali dari kelas komputer sehingga guru memerintahkan siswa yang belum komputer untuk segera ke kelas komputer. Pelajaran komputer di TK tersebut dilakukan secara bergilir beberapa siswa sehingga siswa yang belum mendapat giliran akan tetap mengikuti pembelajaran di kelas seperti biasanya. Baru kemudian jika siswa yang sudah ditunjuk lebih dulu kembali, guru akan menunjuk beberapa siswa untuk gantian menunju ke kelas komputer. Penggunaan kata ya dalam tindak memerintah guru tersebut dapat menunjukkan strategi kesantunan guru secara langsung sehingga jika dituliskan, tuturan guru diakhiri dengan tanda seru. Dengan demikian, tuturan guru yang memiliki kata $y a$ di akhir kalimat merupakan salah satu bentuk kalimat imperatif yang digunakan guru.

Temuan penelitian mengungkapkan bahwa kata seru ya dapat dijadikan sebagai salah satu penanda kalimat imperatif sehingga tindak direktif guru yang melekatkan kata seru ya di akhir kalimat termasuk dalam strategi langsung. Penggunaan kata seru ya dalam tindak direktif guru tidak diungkapkan pada penelitian-penelitian sebelumnya. Ramadhan (2007) memaparkan bahwa modalitas atau penanda kesantunan yang digunakan guru dalam interaksi pembelajaran ialah kata coba, boleh, silakan, dan tolong. Adapun penelitian Suharto (2004) dan Amiruddin (2011) juga belum mengungkapkan adanya penggunakan kata seru ya pada tuturan guru. Sneddon (1996:337) menjelaskan bahwa kata seru ya merupakan salah satu penanda yang dapat menghaluskan kalimat imperatif. Dengan demikian, penggunaan kata seru ya dapat menghaluskan kalimat imperatif meskipun tetap termasuk dalam strategi langsung.

\section{SIMPULAN DAN SARAN}

Strategi kesantunan tindak direktif guru dinyatakan dengan strategi langsung tanpa penanda kesantunan dan strategi langsung dengan penanda kesantunan. Berdasarkan hasil analisis data yang telah dilakukan, dapat disimpulkan bahwa tindak direktif guru yang dinyatakan tanpa penanda kesantunan memiliki frekuensi yang lebih tinggi digunakan dalam interaksi pembelajaran meskipun memiliki derajat kesantunan yang lebih rendah. Hal tersebut dipilih guru untuk meningkatkan keefektifan interaksi pembelajaran.

Berdasarkan temuan penelitian tentang wujud kesantunan, hasil penelitian yang telah dilakukan merupakan potret 
penggunaan bahasa guru dalam interaksi pembelajaran di TK, khususnya kesantunan tindak direktif guru. Pertama, hasil penelitian ini dapat dijadikan sebagai bahan evaluasi dan introspeksi guru dalam berinteraksi dengan siswa TK agar tercipta suasana komunikasi yang santun, empatik, dan efektif melalui bahasa yang digunakan guru. Dengan demikian, guru TK dapat menyadari bahwa bahasa bukan hanya sebagai alat komunikasi, tetapi juga sebagai penyampai rasa santun. Hal tersebut diperlukan agar siswa dapat belajar berbahasa secara langsung melalui pajanan bahasa yang digunakan guru. Untuk itu disarankan kepada guru TK agar lebih memvariasikan strategi kesantunan yang digunakan untuk menyampaikan tindak direktif. Hal tersebut diperlukan dengan harapan siswa memperoleh pengalaman berbahasa dengan santun yang pada akhirnya dapat menjadi karakter siswa.

Kedua, hasil penelitian dapat dijadikan sebagai bahan pertimbangan bagi para pengembang bahan ajar agar menyajikan contoh penggunaan bahasa yang santun dan lebih bervariasi sebagaimana fenomena penggunaan bahasa yang terjadi di kelas. Para pengembang bahan ajar dapat mempertimbangkan berbagai aspek, misalnya latar belakang siswa, kebutuhan siswa, dan perkembangan psikologis siswa sehingga bahan ajar yang dikembangkan dapat mendukung tercapainya tujuan pendidikan anak usia dini, khususnya dalam berbahasa dan bersikap.

\section{DAFTAR PUSTAKA}

Amiruddin. 2011. Penggunaan Kesantunan Tindak Direktif Berbahasa Indonesia Guru dalam Pembelajaran di Kelas: Kajian Etnografi Komunikasi di SMP Rappang. Tesis tidak diterbitkan. Malang: Pascasarjana UM.

Austin, J.L. 1962. How to Do Things with Word. New York: Oxford University Press.
Chaer, A. \& Agustina, L. 2010. Sosiolinguistik: Perkenalan Awal. Jakarta: Rineka Cipta.

Chaer, A. 2010. Kesantunan Berbahasa. Jakarta: Rineka Cipta.

Cummings, L. 1999. Pragmatik: sebuah Perspektif Multidisipliner. Terjemahan Eti Setiawati, dkk. 2007. Yogyakarta: Pustaka Pelajar.

Hurlock, E.B. 1980. Psikologi Perkembangan: Suatu Pendekatan Sepanjang Rentang Kehidupan Edisi Kelima. Terjemahan Ridwan Max Sijabat. Tanpa tahun. Jakarta: Erlangga.

Ibrahim, A. S. 1993. Kajian Tindak Tutur. Surabaya: Usaha Nasional.

Depdiknas. 2007. Kerangka Dasar Kurikulum Pendidikan Anak Usia Dini. Pusat Kurikulum BalitbangDepdiknas. (Online), (http://file.upi.edu/FIP/PAUD/SIPAUD), diakses 29 Agustus 2015.

Leech, G. 1983. The Principles of Pragmatics. Terjemahan M.D.D. Oka. 1993. Jakarta: Universitas Indonesia Press.

Rahardi, K. 2009. Sosiopragmatik. Jakarta: Erlangga.

Ramadhan, S. 2007. Representasi Kesantunan Tindak Tutur Berbahasa Indonesia Guru dalam Interaksi Pembelajaran di Kelas. Disertasi tidak diterbitkan. Malang: Pascasarjana UM.

Ramlan, M. 1986. Ilmu Bahasa Indonesia: Sintaksis. Yogyakarta: Karyono.

Searle, J. 1981. Expression and Meaning. Cambridge: Cambridge University Press. 
Sneddon, J.N. 1996. Indonesian: a Comprehensive Grammar. New York: Routledge.

Suharto. 2004. Kesantunan Berbahasa Indonesia dalam Interaksi BelajarMengajar di Kelas 2 SLTP. Tesis tidak diterbitkan. Malang: Pascasarjana UM.

Suyitno, I. 2004. Pernik-Pernik Berbahasa: Pemahaman Lintas Budaya. Malang: Sentra Media.
Taylor, I. 1990. Psycholinguistics: Learning and Using Language. United State: Prentice-Hall.

Yule, G. 1996. Pragmatik. Terjemahan Indah Fajar Wahyuni dan Rombe Mustajab. 2006. Yogyakarta: Pustaka Pelajar.

Yus, A. 2011. Penilaian Perkembangan Belajar Anak Taman Kanak-Kanak. Jakarta: Kencana. 